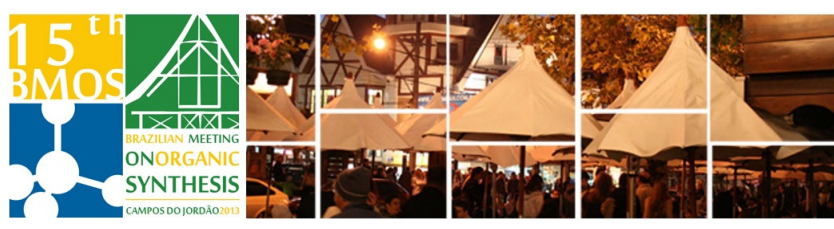

\title{
Chemoenzymatic Enantiospecific Synthesis of a Fluorinated myo-Inositol Analogue
}

Angelo Amaro T. da Silva, ${ }^{a}$ Aline G. Cunha, ${ }^{a}$ Evelin A. Manoel, ${ }^{\mathrm{b}}$ Denise Maria. G.

\author{
Freire $^{\mathrm{b}}$ and Alessandro B. C. Simas ${ }^{\mathrm{a} *}$
}

a Universidade Federal do Rio de Janeiro (UFRJ), Instituto de Pesquisas de Produtos Naturais (IPPN), Lab.

Roderick A. Barnes, CCS, bloco H and ${ }^{b}$ UFRJ, Instituto de Química, Depto. Bioquímica, CT, bloco A, $5^{\circ}$

andar - Ilha do Fundão, Rio de Janeiro, RJ, Brazil

*e-mail corresponding author: abcsimas@nppn.ufrj.br

Keywords: Enzymatic resolution, myo-inositol, fluorine

\section{INTRODUCTION}

Inositol derivatives play important roles in biological systems. $^{1 \mathrm{a}-\mathrm{c}} \quad$ D-myo-Inositol 1,4,5-trisphosphate [Ins(1,4,5)P3] (1) is a major second messenger associated with many cellular signaling processes (Figure 1). ${ }^{1 \mathrm{a}-\mathrm{c}, 2}$ Among other analogs, fluorinated inositols have been studied as biological probes for pathways involving cyclitol biotransformations. ${ }^{2,3}$

Herein, we describe an enantiospecific synthesis of 1L-(-)-4-deoxy-4-fluor-myo-inositol [(-)-2] via an enzymatic kinetic resolution approach (Figure 1). ${ }^{2 \mathrm{~b}}$

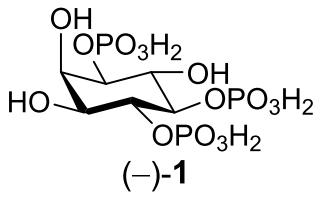<smiles>OC1C(O)C(O)C(O)C(O)C1O</smiles>

$(-)-2$

Figure 1. $\mathrm{IP}_{3}$ and a fluorinated analogue of myo-inositol.

\section{RESULTS AND DISCUSSION}

Recently, our group developed and optimized an efficient enzymatic resolution of diol ( \pm )-3 leading to (-)-4. (Scheme 1). . $^{4 a}$

myo-insoitol<smiles>COC(C)(C)[13CH]1CO1</smiles>

$$
\text { steps }
$$
Novozym 435, BnO vinyl acetate, $13 \mathrm{~h}$ $( \pm)-3$ $\mathrm{OH}$

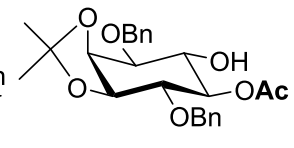

(-)-4 49.3\% (>99\% ee)

Scheme 1. Enzymatic resolution of monoacetate 3.

Thus, we studied the deoxofluorination reaction of enantiopure (-)-4 (Scheme 2)..$^{5}$ Use of DAST in $\operatorname{DCM}\left(\mathrm{CH}_{2} \mathrm{Cl}_{2}\right)$ or toluene with DMAP $\left(60^{\circ} \mathrm{C}\right)$ resulted in low yields of (+)-5. However, we found that a cleaner and faster reaction was achieved with DAST (5.0 equiv.) in excess (toluene, no base, r.t.) (under optimization). With XtalFluor-E in DCM, fluoride (+)-5 was not formed. Analyses of $1 \mathrm{D} / 2 \mathrm{D} \mathrm{H}^{1}, \mathrm{C}^{13}$ and $\mathrm{F}^{19}$ NMR confirmed the formation of compound (+)-5, with retention of relative configuration.

After two successive hydrolyses, triol 7 was obtained in $84 \%$ overall yield. A straightforward catalytic hydrogenation catalyzed will provide the final target, $(-)-2$.

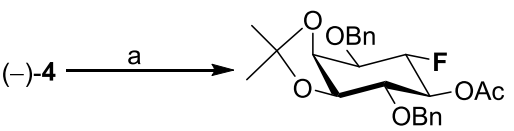

(+)-5 $43 \%$

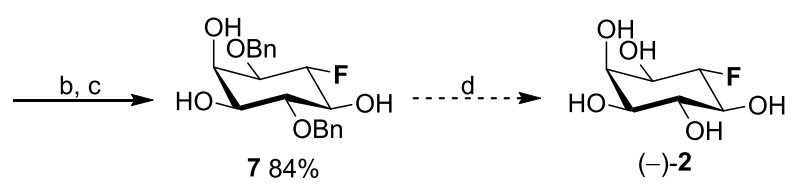

(a) DAST, PhMe, r.t., $1 \mathrm{~h}$; (b) $\mathrm{NaOH} 10 \%, \mathrm{MeOH}$, r.t., 30min, then Amberlite IR-120; (c) EtOH, $\mathrm{H}_{2} \mathrm{O}$ (3 eq.), PTSA, $90^{\circ} \mathrm{C}$, 3h, then $\mathrm{Et}_{3} \mathrm{~N}$; (d) $\mathrm{H}_{2}, \mathrm{Pd} / \mathrm{C}$

Scheme 2. Synthesis of L-(-)-2.

\section{CONCLUSION}

The underdeveloped application of lipases to enantioselective synthesis of inositols proved fruitful. Following the necessary optimization of the deoxyfluorination, a practical and economical synthesis of L-(-)-2 will become available.

\section{ACKNOWLEDGEMENTS}

We thank CNPq, UFRJ and FAPERJ for funding and fellowships.

\section{REFERENCES}

1 (a) Best, M. D.; Zhang, H.; Prestwich, G. D. Nat. Prod. Rep. 2010, 27, 1403. (b) Michell, R. H. Nat. Rev. Mol. Cell Biol. 2008, $9,151$.

(a) Ballereau, S.; Guedat, P.; Poirier, S. N.; Guillemette, G.; Spiess, B.; Schlewer, G. J. Med. Chem. 1999, 42, 4824. (b) Offer, J. L.; Voorheis, H. P.; Metcalfe, J. C.; Smith, G. A. J. Chem. Soc., Perkin Trans. 1 1992, 953.

${ }^{3}$ Einicker-Lamas, M.; Malaquias, A. T.; de Castro, S. L.; Smith, G. A.; Oliveira, M. M. Parasitol. Res. 1999, 85, 232.

${ }^{4}$ (a) Cunha, A. G.; da Silva, A. A. T.; da Silva, A. J. R.; Tinoco, L. W.; Almeida, R. V.; de Alencastro, R. B.; Simas, A. B. C.; Freire, D. M. G. Tetrahedron Asymmetr. 2010, 21, 2899. (b) Cunha, A.

G.; da Silva, A. A. T.; Godoy, M. G.; Almeida, R. V.; Simas, A. B.

C.; Freire, D. M. G. J. Chem. Technol. Biotechnol. 2013, 88, 205.

${ }^{5}$ L'Heureux, A.; Beaulieu, F.; Bennett, C.; Bill, D. R.; Clayton, S.; LaFlamme, F.; Mirmehrabi, M.; Tadayon, S.; Tovell, D.; Couturier, M. J. Org. Chem. 2010, 75, 3401. 